\title{
Un-doing Labour in Greece: Memoranda, Workfare and Eurozone 'Competitiveness' ${ }^{\text {' }}$
}

\author{
Christos Boukalas, Cardiff Law School, United Kingdom \\ Julian Müller, SOMO, The Netherlands
}

\begin{abstract}
This article examines the assault on the rights, wages and bargaining position of workers in Greece following the bailout agreements between Greece and its creditors - the European Central Bank, the International Monetary Fund (IMF) and the group of Eurozone countries. It focuses in particular on the workfare measures that are designed to activate the industrial reserve army. These measures are enacted in the name of competitiveness, which is defined as reducing unit labour costs, revealing the neo-liberal orientation of the structural adjustment programme to which Greece is being subjected. The article also puts this into the context of the wider conflict over austerity policies in Greece, which came to a head with the election of the left-wing Syriza party in January 2015 and its recent defeat against the country's creditors. We argue that this result can only be properly understood if the institutional design and inherent selectivities of the Eurozone are taken into account.
\end{abstract}

\section{Introduction}

Greece is living a moment pregnant with history. We write this article in the wake of the capitulation of Greece's left-wing government to the demands of the country's creditors. This, in turn, came on the heels of a referendum on 5 July 2015 in which Greeks rejected the new round of devaluation of life and labour that the creditors had 'proposed' - and to which the Syriza government was forced to surrender days later, despite the referendum's result.

The ${ }^{\dot{o} \iota_{\mathrm{t}}}{ }^{2}$ was a gesture of class resistance. There is a strong correlation between income and the vote - the lower the income, the higher the 'no' vote and vice-versa (The Guardian, 2015). Most importantly, the 'no' vote had to overcome tactics employed by (domestic and international) capital that amounted to open class war. The week preceding the vote saw: (a) the withdrawal of liquidity to Greek banks by the European Central Bank (ECB), which led to cash rationing and capital controls, which in turn triggered scarcity in basic goods; (b) a paroxysm of domestic capital's mouthpieces (the mainstream media) about the catastrophic consequences of a 'no' vote (TVXS, 2015); and (c) employers ceasing to pay their workers and threatening to fire them if 'no' won (Efsyn, 2015). Facing this unprecedented assault on workers, the National Union of Private Sector Workers (GSEE/ $\Sigma \mathrm{EE}$ ) aligned with capital, declaring the referendum invalid and pushing for a 'yes' vote (GSEE, 2015). Against all these, the ó $\chi \iota$ constitutes a resounding victory of popular resistance. It smashed the tactical game played by Syriza around the referendum, showing that the government and the party are superseded by society, and rendering them unable to manage the result (EvansPritchard, 2015; Varoufakis, 2015).

Those terms of class warfare were acute expressions of conditions already imposed on working people over the last five years. In the era of the Memoranda, Greece is the advanced 
laboratory of neo-liberal policy. It is the site of a massive attack by capital on society, but also the terrain of fierce social resistance. From the numerous general (and countless sectoral) strikes, mass demonstrations, extensive riots and occupations of governmental buildings that marked the 20102012 period, to the election of a left-wing government in January and the ó society has used almost all conceivable means of resistance - so far to no avail. This article focuses on a central facet of the capitalist assault and deciphers the strategies and structures from where it emanates.

It examines the recasting of labour relations in Greece under the auspices of the Memoranda. As little attention has been paid to this crucial issue, the article pursues it in detail. It also suggests that labour reform in Greece is integral to a broader EU/Eurozone economic strategy that synthesises the interests of a continental power bloc $^{3}$ comprising finance (which has an interest in a strong Euro) and large, export-oriented, industrial capital (which seeks competitiveness in the world market). This strategy shapes the Eurozone as a supply-side, export-oriented economy, and involves the creation of zones of cheap labour within the Eurozone.

In the following sections we, first, provide an overview of the period from the first Memorandum of Understanding (MoU), until the óx l and the agreement of the third Memorandum. Then, we examine labour reform in Greece from 2010 to the present as it is described in the Memoranda, national law and executive decisions. We do so in two instalments, one referring to regular forms of labour, the other to workfare programmes that insert the unemployed in the labour market in very peculiar terms. In the last substantive section, we show this reform to be part of a Eurozone-wide economic strategy that is deeply entrenched in, and helps to shape, the political and economic structures of the European Union (EU). Finally, we briefly outline some orientations and dilemmas for the left in the context of a deeply neo-liberal EU.

\section{Background: The Greek Crisis}

By 2010, the financial crisis that began in 2007 in the United States (US) real estate market and financial sector had been transformed into a sovereign debt crisis that affected various members of the Eurozone, the monetary union that currently includes nineteen EU member states. Following an increase of their public debts and rating downgrades, Greece, Ireland, Portugal, Spain and Cyprus were forced to request financial assistance from the Eurozone and International Monetary Fund (IMF).

This financial assistance came with the kind of conditionalities that developing countries that have had to access IMF loans have long been used to: austerity measures to cut fiscal deficits and debt ratios, privatisation, labour market 'reforms', reducing pension entitlements, shrinking the public sector and so on. These measures were hugely contentious in most of the affected Eurozone countries, but nowhere more so than in Greece where the economy has shrunk by a quarter, and unemployment exceeds $25 \%$ and stands at around $45 \%-50 \%$ for young people (Hellenic Statistical Authority, 2015). Fierce struggles raged from 2010 until 2012, but failed to stop the onslaught of austerity, mass dismissals and other measures that have since caused a social and humanitarian crisis. Austerity did not reduce the debt burden on the Greek economy; instead it increased it. In 2010, when Greece first sought financial assistance, the country's debt-to-GDP ratio stood at 146\%; in 2014 it stood at 176\% (European Commission, 2015).

At the same time Greece also saw the emergence of Syriza, a left-wing party formed barely ten years before as a broad coalition of the left that, around a Euro-left core, included Trotskyists, ecosocialists, feminists and Maoists. The party managed to become the main representative of popular dissatisfaction with the austerity programme and came a close second in the 2012 general election.

Global Labour Journal, 2015, 6(3), Page 391 
When the Greek Parliament failed to elect a new Greek president, snap elections were called for January 2015. Syriza won and formed a government, causing great concern among other EU leaders. Tense negotiations between Greece and the so-called 'Troika' of lenders - the European Central Bank, the IMF and the European Commission - over the conditions of the bailout began shortly after the election.

Syriza went into these negotiations with two priorities: to stop/reverse austerity, and to keep Greece in the Eurozone. These two priorities were of equal importance; there was no hierarchy between them and both had to be achieved. It was impossible to decide what to do if they proved mutually exclusive. They could not decide - or threaten - to leave the Euro. Given Greece's small economy and lack of political clout in the European Union, this threat would have been their only bargaining chip. This two-headed position resulted from an electoral please-all strategy that Syriza adopted in 2012 when gaining power became a real possibility. It was not just a 'communicative' tactic, but reflected a genuine ambiguity within the party. More importantly, it reflected a deep ambiguity in society, the majority of which is keen on remaining in the Eurozone.

Unable to drive a hard bargain, the Syriza government set its hopes on debt forgiveness, citing a 1953 debt relief agreement between West Germany and its creditors as a historical precedent. Predictably, the Troika would have none of that, and an agreement reached in February 2015 saw the government gain a four-month extension of the financial assistance programme, in exchange for which it had to commit itself to honouring all existing obligations entered into by previous governments, including full repayment of Greek sovereign debt. Moreover, the government had to submit to the Euro-group a plan for reform. No disbursements of financial assistance would take place without Euro-group approval of this plan.

Several months of tough negotiations followed in which each side presented diverging drafts of the reform list to be agreed on. Debt repayments that became due in this period were met by the Greeks through increasingly desperate measures like raiding the cash reserves of local governments and other government-controlled entities. Crunch time came in June 2015. The government was faced with a repayment due to the IMF on June 30, but had exhausted all possibilities of scraping together cash or delaying payments. Greece would not be able to pay unless it received financial assistance from the creditors. In line with its commitment not to seek or threaten exit from the Eurozone, the Greek government made substantial concessions and also extracted some minor concessions from the creditors.

However, disagreement over crucial issues like pension cuts, labour reform and the size of the primary budget surplus ${ }^{4}$ persisted. On June 26 prime minister Tsipras pulled out of the negotiations and announced that a referendum would be held on the latest bailout deal offered by the country's creditors. On July 5 the bailout deal was rejected by the Greek people with a majority of $61 \%$ - the now-famous ó $\chi$ l.

However, the government did everything not to frame the referendum as a decision over whether to accept austerity in order to stay in the Eurozone, or to reject austerity even if it meant exit. In fact, it went back to negotiations with a proposal that was substantially the same as the one the Greek people had rejected. Rather than accepting it, the creditors, led by Germany, continued to play hardball and on July 12 forced Tsipras to accept an even harsher, almost humiliating, agreement in exchange for a conditional promise to begin negotiations on a third bailout loan. ${ }^{5}$ This new agreement not merely included commitments to further austerity and privatisation, it also committed the Greek government to ensure passage of a number of laws on VAT, pensions, independence of the national statistical office and judicial reform. It was so intrusive that a Deutsche Bank note to its clients reportedly stated: 'The proposals barely stop short of demanding that Greece becomes a vassal state of Brussels' (Mackintosh, 2015). The Syriza government got the required laws through 
Parliament, but only with the help of opposition MPs as it was faced with numerous defections from its own left wing.

For the time being, austerity, privatisations and the rollback of social and labour rights are set to continue in Greece, but the medium-term future is anything but clear. The Syriza government has lost its parliamentary majority. As a result, prime minister Tsipras resigned on August 20 and called snap elections for 20 September 2015, while the rebellious left wing of Syriza has formed a new party. In August 2015, a third Memorandum was agreed in line with the July agreement. The measures demanded by the creditors will probably exacerbate the economic and social crisis while doing nothing to reduce Greece's debt-to-GDP ratio and improve the country's ability to service its debt. A repeat of the stand-off from early 2015 is therefore possible. The situation has not been resolved and the question of debt relief or a Greek exit from the Eurozone - Grexit - may be raised again, either by popular resistance to crushing austerity and recession, or by the creditors themselves who might generously decide to restructure the country's unsustainable debt. This latter option can only happen as a reward for Greek compliance and not as a concession to popular struggles that might encourage others - in other words, if the creditors conclude that resistance has been defeated and no longer poses a threat to the competitiveness-oriented restructuring of the Eurozone economies and societies. We turn now to this restructuring.

\section{New Model Labour}

Until the recent surrender of the Syriza government to Greece's creditors, labour relations and pension reform were the two most contested issues between Greece and its creditors. In anticipation of the terms of surrender in the third Memorandum, and expecting a further dismantling of labour protections, we overview the landscape of labour relations as it has been forged in five years of Memoranda.

\section{Greece's new labour: poor, atomised, 'competitive'}

The second Memorandum (MoU 2012; ratified by law N.4046/2012) identifies three primary challenges facing Greece: unsustainability of public sector finances, lack of banking sector liquidity, and most importantly weak competitiveness. Competitiveness is defined exclusively as labour cost per unit. This already indicates the strategic orientation of the $\mathrm{MoU}$ and the ideological leaning of its authors. First, competitiveness is identified with labour cost, indicating that Greece is destined to be a low-cost, law-value economy. Second, wages are conceptualised as cost of production rather than source of demand, a supply-side approach revealing the neo-liberal character of the project (Jessop, 2002: 152-9).

To strengthen competitiveness, the Memorandum dictates that Greece will implement structural reforms to increase productivity and improve its 'entrepreneurial environment'. Most of all, it will lower labour cost per unit by 15\% through wage cuts and labour market restructuring. It will also encourage Foreign Direct Investment (FDI) by significantly reducing the influence of the state in the economy, privatisation of public assets and 'daring' public spending reduction, for recovery will come from the private sector. The Memoranda impose a two-pronged strategy, comprising drastic devaluation of labour and shrinkage of the public sector. Importantly, setting the attraction of FDI as the ultimate goal of both sides of the project testifies that the latter is designed to serve mainly transnational export-oriented capital.

The supra-national directorates that authored the MoU provide not only the broad parameters of the reform project, but dictate measures in detail. Thus, 'daring structural reforms' in the public sector means drastic wage cuts, so that wages amount to less than $9 \%$ of GDP, and reductions of 
public sector personnel by at least 150000 people by the end of 2015 .

But the top priority is reduction of unit labour costs by $15 \%$ through structural reform of the labour market. That is, Greece would reform collective agreements so that they do not last for more than three years. If they are not replaced by a new agreement after ending, wages are automatically set to the legal minimum.

The lowest wage per grade would be lowered by $22 \%$ - and by $32 \%$ for those under 25 years of age - and frozen until the end of 2015. Similarly, wage increases due to maturation are prohibited until unemployment falls below 10\%. (In the context of the Greek reality, this means 'forever'.) Moreover, the Memorandum dictates that non-wage costs be brought down, mainly by legislating a $5 \%$ reduction of employers' contribution to social insurance. Finally, unilateral resort by labour unions to industrial arbitration would be banned, and arbitration must not be based only in law but take account of the broader financial and economic climate. All this is done in order to bring labour cost in Greece in line with that of 'our competitors', namely Portugal, and the countries of Central and South-eastern Europe. According to the IMF deputy director for Europe, Greece is a Balkan country and therefore $€ 300$ salaries would be 'about right' (The Press Project, 2015).

In sum, it is plain that the Memoranda policy for Greece is a coherent project undertaken by supra-national directorates (with the synergy of Greek governments), on behalf of transnational, export-oriented capital (with collateral benefits for indigenous capital, which is mainly comprador ${ }^{6}$ ). The project consists of a radical devaluation of labour - through wage cuts, mass layoffs, restructuring work relations to the benefit of capital, drastic reductions in social and welfare spending, and the decline of labour law.

Labour reform in Greece is nothing but the implementation of these dictates. It focuses persistently on wage cuts, flexibilisation of wage and time, facilitation of dismissals, and the restructuring of arbitration and collective bargaining (European Commission, 2010a; 2010b; Voskertsian and Kornelakis, 2011: 7).

The 2012 N.4046/2012 imposes a wage freeze until unemployment falls under 10\%, as dictated by the Memorandum (Amargiotakis, 2015: 16-18). Moreover, it authorises the Cabinet to unilaterally set the minimum wage for private sector workers, without the need to resort to Parliament, and 'according to the situation and prospects of the economy and the labour market in conditions of high unemployment'. Accordingly, Cabinet Act No.6 (2012) sets the minimum wage for white collar workers at $€ 586$ ( $€ 511$ for those under 25 years of age), and at $€ 26$ per day for blue collar workers (€22,8 for those 25). Finally, it sets the benefit for the long-term unemployed to $€ 200$ monthly, payable for only one year, and stipulates that its overall cost cannot surpass $€ 300$ million yearly.

This is added to earlier measures, introduced in the wake of the first Memorandum. Law N.3863/2010 reduced overtime pay by 20\%. Law N.4024/2011 reduced the scope of overtime pay so that if overtime is less than two hours and occurs before 22:00 it is paid at the normal rate. Importantly, part-timers must be occupied for $8+2$ hours in order to qualify for overtime pay, blurring the distinction between part-time and full-time work. N.3899/2010 established that overtime is legal as long as the enterprise needs it, and that workers' refusal to work overtime when they are able to amounts to bad faith.

Finally, the dismissal of workers is made cheaper and easier. N.3863/2010 raises the ceiling of the number of workers a firm can legally fire monthly. N.3899/2010 provides no compensation at all for fired workers who have been in the firm for less than a year (thus raising probation time from two to twelve months). N.4093/2012 combined with Cabinet Decision 6/2012 lowers compensation by reducing the warning time required (Amargiotakis, 2015: 49).

Memorandum-dictated policy also recasts the legal framework of class struggle, by reforming

Global Labour Journal, 2015, 6(3), Page 394 
collective bargaining and the arbitration of industrial disputes. While it does not upset the core structure or competences of arbitration, N.4303/2014 imposes as decisive criterion for the arbiter's decision the 'economic and financial features, the development of competitiveness, the financial situation of the weakest enterprises ..., the progress in reducing the competitiveness gap, and the reduction of cost per labour unit...' (Art.4). Moreover, the law provides for judicial control to ensure that decisions comply with this criterion. Thus, arbitration is not guided by law nor determined by the specific issues arising from the negotiations. It is merely a lever to reduce labour costs and cannot but align with the interests of the employer.

Collective bargaining was reshaped by N.4024/2011. It allows workers in every firm, regardless of size, where unions are not operative, to form 'associations of employees' (AoE), as long as $60 \%$ of the firm's workforce (regardless of grade) signs up. These associations are not unions, and they are completely unregulated; even their independence from the employer is neither stipulated nor safeguarded. They have capacity to negotiate and sign collective agreements with the employer (N.3899/2010). Crucially, firm-level agreements, whether signed by a union or by an AoE, take precedence over sectoral agreements, even if they contain worse terms. The rationale behind this reform was to bring wages in line with productivity, firm-specific needs and market conditions (Amargiotakis, 2015: 7-8; Dauli et al., 2013: 3; Deakin and Kouliadaki, 2013: 183; Voskertsian and Kornelakis, 2011: 18-19). Moreover, by stating that only employers who belong to employers' unions are tied by wage specifications in national collective agreements, law N.4093/2012 precludes sectoral and general collective agreements from touching the wage at all (Amargiotakis, 2015: 8). Thus, the floor for the wages of the vast majority of workers is the legislated minimum wage.

Since the law was introduced, firm-level contracting has soared almost tenfold. It predominates in manufacturing, hospitality, wholesale and retail. Almost all firm-level agreements either reduce wages $(81 \%)$ or keep them frozen $(18 \%)$. The average wage cut is $10 \%$, while in many cases cuts reach $45 \%$. Firm-level agreements tend to bring the wage to the national minimum. Especially the agreements negotiated by AoEs are significantly more likely to introduce wage cuts and, when they do, these cuts are deeper than those negotiated by unions $-65 \%$ of AoE agreements surrender to the national minimum. Indeed, the presence of a union or an AoE is the most decisive factor regarding the extent of the cuts (Dauli et al., 2013: 4-5, 8-11).

If an agreement cannot be reached at firm level, then, instead of reverting to the sectoral agreement, the employer negotiates individually with each worker. It is estimated that about $90 \%$ of Greek businesses, employing $80 \%$ of private sector workers, have no collective agreement of any kind, but operate on terms determined unilaterally by the employer (Syriza, 2014: 2; Voskertsian, 2015: 3). If the employers decide that even this does not suit them, they can opt to join the informal economy, which is estimated at about 30\% of GDP. No law applies there, work is undeclared and wages are often agreed under the table (Voskertsian and Kornelakis, 2011: 25).

Thus, labour reform means a steep rise of individual contracts, marginalisation of collective bargaining at every level, fixing of arbitration against the workers, decline of legal protections and a rise of precarious, flexible and unregulated forms of employment (Voskertsian and Kornelakis, 2011: 26). This reform is premised on the dogma that weak competitiveness is due to excessive legal protection of workers and labour market rigidity, despite there being no evidence that wage and standards reduction enhances competitiveness (Deakin and Koukiadaki, 2013: 176; Armingean and Bacaro, 2012). Indeed, as a combined effect of the above measures, it is estimated that Greek private sector workers have lost half their spending power without any strengthening of the country's competitiveness as a result (Syriza, 2014: 2). In other words, the 'strengthening of competitiveness' sounds suspiciously like a euphemism for the enhancement of capital profitability through expanded exploitation. $^{8}$ 
This direction of travel is common for many European countries, even some that have not received the Memorandum treatment. It typically bypasses domestic actors. There is no discussion or contestation between domestic social forces, and even national parliaments are circumvented, as measures are often introduced through emergency procedures and executive decrees (Deakin and Kouliadaki, 2013: 176-7; Voskertsian and Kornelakis, 2011: 28; Villiers, 2014: 84). In Greece in particular, the labour reform measures are seen, both in procedure and substance, as blunt violations of the Constitution (Chryssogonos, 2013). It further points to an assumption of core nation-state competences by transnational directorates, which also change in the process. Thus, in Greece the EU assumes full control over social and labour policy, completely reversing its long-established stance of acknowledging these issues as the competence of core member-states (Deakin and Kouliadaki, 2013: 164-72).

\section{Workfare: labour as 'benefit' and as punishment}

Still, the most advanced restructuring occurs not in the field of labour proper, but through the introduction of the 'reserve army' in the labour process.

The establishment of workfare in Greece takes the form of a forceful introduction of unemployed people into the labour market, as their entitlement to unemployment benefits becomes conditional on their acceptance of work placements.

There are two main workfare programmes: one that places the unemployed in 'training schemes' in the private sector; and another that, without 'educational' pretences, inserts the unemployed into public sector jobs. We shall discuss both, starting from the latter, known as the Public Benefit Programme (PBP).

The PBP is co-funded by the Greek state and the European Social Fund. It aims to alleviate the plight of the unemployed and address social needs by engaging its unemployed 'beneficiaries' in public benefit work. There are 50000 'beneficiaries' currently engaged in the Programme but PBP is projected to engage 400000 people when fully operational (Skya, 2015: 25).

The Programme was introduced not by parliamentary law, but by two separate Ministerial Decisions (Greek Gov., 2011a; 2014a). Candidates apply for positions advertised by public or thirdsector organisations. Their applications are prioritised according to a range of criteria. The contract lasts for five months.

Crucially, the successful candidates who take up temporary public sector employment are not recognised as workers, but merely as beneficiaries. They are therefore fully exempt from labour law and collective agreements (Skya, 2015: 5). They are paid below the minimum wage, have no right to leave (not even for illness), no capacity to decline or be paid extra for overtime, no capacity to challenge their boss (who is not an 'employer' but a 'supervisor'), even when the employer subverts the terms of the contract, and certainly no right to unionise or take collective action (Skya, 2015: 6, 21). Similarly, their payment - which is not a salary but an 'informal allowance' - is conditional. It comes in three instalments, two of which are paid once the relevant authorities have assessed the success of the specific placement programme and the beneficiary's performance therein. Finally, in December 2013, the Organisation for the Occupation of Labour (Greek initials: OAED) issued a guideline dictating that successful candidates who fail to accept or complete their placement are automatically crossed off the unemployment register and lose all related benefits. Yet, importantly, it seems that in practice this is not happening. Moreover, since early 2014, payments tend to be delivered to the beneficiaries regularly and on a monthly basis, while officially they do not have to be paid. This may be the outcome of fierce wildcat struggles by the beneficiaries (Skya, 2015: 6, 8, 12).

The Programme was set up in two stages - April 2011 and November 2014. The differences among them are worth noting, as they indicate a significant rethink. To begin with, there is a 
recasting of the PBP mechanics, as the key implementing authority has been changed. The first (2011) Ministerial Decision grants the selection of candidates and their distribution to placements to NGOs. These NGOs were in charge of delivering the payment from the PBP funds, keeping a 5\% cut for their services. They were also responsible for assessing the success of each specific programme and placement (Greek Gov., 2011a: 8839-8840). The 2014 decision banished NGOs from the administration of people and payments, and from the evaluation of placements and schemes, handing these functions to the central state authority of the OAED (Greek Gov., 2014a: 37120). What caused this change of heart is unclear, but it may be related to the struggles of the unemployed who saw in the NGO middlemen a relapse into clientelism (Skya, 2015: 8, 11).

The second major change regards the nature of the work itself. The 2011 decision specified that only public sector entities and NGOs could employ beneficiaries, and declared the public benefit character of the work. It was silent regarding its nature, except to explicitly prohibit the use of beneficiaries to cover an organisation's permanent staff needs (Greek Gov., 2011a: 8840). By contrast, the 2014 decision lifts this prohibition, and states that beneficiaries are to be hired across the public sector, with priority given to: (a) local government (especially improvement and conservation of local government infrastructure, expansion and upgrading of cyber and information technologies, and cleaning); (b) education; (c) health (cleaning, reception, computer logistics); (d) other public services in direct contact with citizens (courts, citizen advice bureaus); and (e) actions of social service and support to those in need due to the 'economic crisis' (Greek Gov., 2014a: 37120).

The overall purpose of the Programme was recalibrated accordingly. While in 2011 it was strictly focused on enhancing access to work, in 2014 it was re-oriented towards 'improving citizen service' (Greek Gov., 2011a: 8839; 2014a: 37119). PBP is obviously being used to fill the hole that Memorandum policies have created in the public sector (Skya, 2015: 22-3). As OAED makes 'prior employment in the subject area' a selection criterion (Skya, 2015: 23), it is easy to envision fired workers being re-hired as temporary, devalued and right-less beneficiaries.

Finally, in line with wage-reductions for 'real' workers, the 2014 decision reduces the monthly 'allowance' for beneficiaries from $€ 625$ to $€ 490$ for those over 25 years of age and $€ 427$ for those under 25 (Greek Gov., 2014a: 37123; Skya, 2015: 15-16). This looks suspiciously like the new real minimum wage.

The sudden influx of these radically devalued workers into the public sector undercuts the struggles of the permanent workers and undermines their relatively strong unionisation and legal rights (Skya, 2015: 23). Under the guise of helping the unemployed, the PBP is set to destroy the main bastion of labour resistance - the public sector - by introducing a new, highly exploitative model of labour relations.

Private capital will not be exempt from the opportunities this model presents. Another Ministerial Decision introduced the Training Voucher Schemes, with the overarching objective of the 'improvement of professional training on offer' (Greek Gov., 2011b: 13732). These are training and apprenticeship programmes targeted at unemployed people, especially young graduates. They currently involve approximately 80000 beneficiaries under 30 years of age, and another 15000 between 30 and 60 (KEK, 2015). The selected applicants receive a voucher to the value of $€ 1100$, which they can only use to acquire training by a private employer. Beneficiaries enjoy (state-funded) health insurance for the duration of their apprenticeship. Instead of unemployment benefits, they receive a taxable training allowance. This is paid by the state, amounts to $€ 400$ monthly for university graduates and $€ 373$ for high-school and vocational training graduates, and is received incrementally and with several months' delay (Greek Gov., 2011b: 13742; Skya, 2015: 28).

These apprentices (most of them already skilled) are placed in both blue-collar and whitecollar jobs across the private sector in apprenticeships that last up to six months or 1200 hours

Global Labour Journal, 2015, 6(3), Page 397 
(Greek Gov., 2011b: 13736). The sorting, selection and distribution of payments to the beneficiaries is done by private Professional Training Centres (Greek initials: KEK), which receive $€ 1100$ for each beneficiary, sparking talk of 'middlemen slave-traders' by a community of resistant beneficiaries that seeks ways to organise against all odds (Voucherades, 2015).

The company that receives the beneficiary obtains six months of free labour, as all trainingrelated expenses, materials and infrastructure are covered by public funds (Greek Gov., 2011b: 13742). Settling the question whether voucher programmes are genuine apprenticeships or subsidised labour schemes, the Decision clarifies that large companies can have up to $30 \%$, and small ones up to 70\%, of their workforce made up of beneficiaries (Greek Gov., 2011b: 13738). Moreover, a private company that hires even one beneficiary after the expiration of a voucher scheme is allowed to have up to $40 \%$ of its workforce consisting of beneficiaries, even if it has previously fired permanent personnel (Skya, 2015: 28). The voucher schemes are designed neither to train unemployed people nor to reduce unemployment. They are designed to aid capital and to make the country 'attractive' to private investment by providing free labour. It is no wonder that the mouthpieces of capital demand that unemployment benefits are fully replaced by training vouchers (Holezas, 2014: 23).

Rather cruelly, the PBP and voucher schemes are conjoint with the Minimum Guaranteed Income programme (MGI). In the pilot stage and involving just over 25000 people at present (with a view to include 700000 recipients in its maturity), the MGI is a relief programme for those in extreme need. It sets a minimum monthly income (€200 for a single individual; $€ 500$ for a family with two children), pays the differential to people subsisting below that income, and also grants them reductions on energy and water bills (Greek Gov., 2014b: 35948). If a 'benefitted unit' declines an OAED offer of PBP employment or an apprenticeship, they are automatically cut off the MGI lifeline (Greek Gov., 2014b: 35948, 35955; Skya, 2015: 33-4). In conclusion, we see that Greece turns to its only 'competitive advantage', the infinite pool of its unemployed, and pumps it hard to create a new model of highly exploitative, utterly precarious labour relations. In doing so, it creates a new type of worker - free-floating, infinitely flexible, perpetually available and utterly atomised. This worker is also highly skilled, under-paid and conditionally paid, unable to engage in collective action, without rights, and famished. And, as a 'beneficiary', she is grateful to the employers for hiring her.

The large trade unions have failed to even register the existence of these unemployed-workers and of the new model of labour they represent. Their failure is structural: Greek unions are large bureaucracies committed to negotiating with the state rather than engaging with the shop floor (Voskertsian and Kornelakis, 2011: 23). And, as GSEE showed in the referendum, they are completely disengaged from the workers they claim to represent. This does not mean that this new breed of workers goes unrepresented: they represent themselves. Their brief presence has been marked by numerous impromptu wildcat struggles, springing directly from the shop floor. The new model of labour - and the new type of worker - comes with new forms of resistance.

The Syriza government was committed to reverse the reform. Instead, it has been forced to implement a new round of attacks on labour. Even at this stage, Syriza has managed to keep the issue of labour reform open to further negotiation. But the prospects look grim, especially for the right to strike. In any case, after five years of unmitigated economic disaster, the 'competitiveness' argument sounds hollow. Greek labour reform can only be seen as bare-fisted class struggle between (mainly) transnational capital and the Greek working and middle classes.

\section{The Class and Policy Bias of European Monetary Integration}

The severity and class nature of the reforms discussed above is obvious. National 
governments cannot normally legislate and implement such reforms in a representative democracy in which resistance is as strong, as it has been in Greece. Usually something like this can only be done in an authoritarian or downright dictatorial system, like the Pinochet regime in Chile. However, representative democracy is still in place in Greece and other European countries that underwent similar treatment, although it has certainly been stretched to its limits. How could draconian antilabour laws be passed in Greece in the absence of an exceptional state form??

The Greek experience demonstrates that European integration, and monetary integration in particular, has created an institutional structure that makes it possible to push through neo-liberal policies that would have a much lower chance of success in a, more or less, national political system under representative democracy. Conversely, it has become more difficult at the national level to implement policies that are associated with the post-war class compromise, such as Keynesian fiscal stimuli, redistributive taxation, activist industrial policy, an expansive welfare policy and so on. Moreover, the EU has proven to be almost impenetrable to left-wing forces. Fierce struggles of a clearly left-wing bent in a number of member states, that would have had significant impact on policies if they were decided at the national level, failed even to cause a dent in the balance of power in Brussels.

A complex, multi-level institutional ensemble has evolved in Europe since the 1980s when the European Single Market was launched. It includes transnational or genuinely European institutions such as the European Court of Justice and the ECB, inter-governmental institutions like the Council of the European Union, and occasionally sub-national governments. It has also dispersed authority over a number of levels and institutions, often with limited democratic accountability. It privileges or explicitly enshrines policies based on the principles of competitiveness, workfare, free access to national markets, free flow of capital and budget consolidation (Ziltener, 1999; Van Apeldoorn, 2002). It is therefore inherently more amenable to liberal supply-side policies and to capital fractions with an international, rather than a domestic, orientation for which wages are a cost of production rather than a source of aggregate demand. In short, what has been termed the European system of 'multi-level' or 'multi-dimensional' governance is far from a level playing field (Holman, 2004). Labour representation is relatively ineffective, and the left never managed to get a foothold at the European level. ${ }^{10}$

The European Monetary Union (EMU), the common European currency with its attendant institutions like the ECB and the Euro-group, the latter being the meeting of the Eurozone's finance ministers, is transnational but inherently asymmetric. This does not formally prescribe an economic model or a hierarchy between member states, but some are privileged over others. Germany in particular has taken a leading role in enforcing the model of a fiscally balanced export-oriented economy that competes for world market share through curbing labour costs and social rights and activating the industrial reserve army through workfare. This is a model that Germany itself has implemented successfully since the introduction of the Euro in 1999. Since then, the good German export performance has not been based on productivity gains or product innovation, but mostly on below-average growth of labour unit costs (Lapavitsas, 2013: 290-2). ${ }^{11}$

Moreover, the EMU added fiscal consolidation as another explicit goal. When the EMU was conceived in the early 1990s, it already included fiscal stability among the so-called convergence criteria: to qualify for Euro membership a country had to have a debt-to-GDP ratio of no more than $60 \%$ and a current budget deficit of no more than 3\%. A few years later, these criteria were made into permanent targets through the Stability and Growth Pact, adherence to which was to be monitored by the Commission. During and in response to the Euro crisis, the European Fiscal Compact and the 'Sixpack' - a bundle of six European regulations that aim to coordinate fiscal policy across member states and avoid macroeconomic imbalances in the EU - further tightened 
these rules. In particular, they tightened budget deficit restrictions by mandating that countries should attain nearly balanced budgets over the medium term, by strengthening the Commission's surveillance and enforcing role, and by introducing automatic fines for countries found in breach of deficit reduction rules. Austerity has thus been constitutionalised at the EU level (Oberndorfer, 2014).

This was the context the Syriza government was confronted with, a context that was hostile to everything that Syriza had promised - as it was soon to find out, particularly when the ECB used its command over liquidity supply to Greek banks to increase pressure on the Greek government. For the Greeks, the Euro is an externally controlled currency, with which, however, they are unwilling to break. Although to the left of Europe's mainstream socialist and social-democratic parties, the Syriza government never wanted to implement a radically left agenda. In the context of recession and hardship it merely tried to enact exactly those Keynesian policies that the European multi-level system systematically obstructs. Insertion into this kind of institutional arrangement makes a Keynesian shift difficult at the best of times - as demonstrated by France in the 1980s. But when you are also a small and heavily indebted country, failure is virtually inevitable.

At the risk of overstating historical continuities, we can say that nothing that has happened in Greece since the first Memorandum in 2010 has come as a surprise. However, it has brought out into the open the biases and fault lines that pervade European integration and the EMU in particular. It has also brought into sharper relief the nature of the power bloc that currently holds sway over the EU. This power bloc appears to combine outward-looking, export-oriented fractions of transnational capital in various EU member states with the governments of those member states that follow a particular model of capitalist accumulation. ${ }^{12}$ It stands under the political leadership of Germany, whose traditionally export-oriented industry and preference for wage moderation and price stability, together with its economic weight, make it the champion and primary enforcer of competitiveness-oriented restructuring in the EU (Financial Times, 2015).

\section{Conclusion}

The power bloc that controls the European Union has seen off another challenge to how it wants the EU to be run, the most serious so far. This raises questions about what it means to do left-wing politics at (or against) the European level. The institutional structures of the European Union, and the Eurozone in particular, have once again proven to be an exceptionally difficult terrain for the left and a formidable bulwark against it. The opposition to Troika-imposed austerity and restructuring in Greece, Portugal, Ireland and Spain in recent years would certainly have swayed national politics, but has failed to influence policies at the European level. At the same time, Greece's integration into the European multi-level system prevented it from putting into practice what the balance of forces in Greek society would have allowed it to do, namely to try out a different path of economic development (still, of course, within the bounds of capitalism).

For the European left it raises the strategic question of whether it should work to dismantle as far as possible the powers of the European Union and advocate retreat from it, or whether it should try to use resistance at the national level to disrupt the neo-liberal European project so as to gain the time and space to formulate an alternative for Europe. The latter would mean to rise above the stale alternative between nostalgic (and potentially dangerous) retreat to the nation-state and uncritical embrace of the 'European project' in its current form (Sablowski, 2015; Jones, 2015; Etievant, 2015).

Paradoxically, it is the very sclerosis of the EU strategic arrangement that could force upon societies a third option. Its incapacity (or unwillingness) to tolerate even modest Keynesianism could force upon popular conscience the rejection not only of austerity and neo-liberalism, but of 
capitalism tout court. The quasi-sadistic treatment of systemic left-wing parties that act through institutional channels and their failure to protect their societies from famine can force popular movements to act beyond and against the institutional context. Practical answers on how to live without capitalism are thus far extremely limited and unconvincing. But, in Greece at least, the question has been raised and informs the horizon of political thinking and action.

We repeat: the moment is pregnant with history. And it is a long moment. Societies have a long way to go, whichever of the routes identified above they may follow - and changes of direction along the way are more than likely. What makes 2015 an historic moment is that the spectre in the first page of the Communist Manifesto tentatively starts to reappear over Europe, after long years when everyone thought it exorcised. It is ungrounded to suggest that it will gather mass and haunt the nightmares of the Masters of Europe, but there is equally nothing in the strategy and constitution of the power bloc that would appease it and put it back in its bottle.

\section{NOTES}

${ }^{1}$ The authors wish to thank Telemachos Antonopoulos, Alex Gallas and Ageliki Serafim for their invaluable contribution of material and ideas.

2 'O $\chi$ ' ' means 'No' in Greek. It was the option in the referendum ballot paper that rejected the creditors' proposal - and which won an astonishing $61.3 \%$ of the vote.

3 'Power bloc' refers to a long-term strategic alliance of different sectors of dominant capital as they are forged in, expressed through, and shape the state - or, in our case, supra-national directorates (Boukalas, 2014: 44-5; Buckel, 2011: 157; Demirović, 2011: 265-6; Jessop, 1982: 166; Poulantzas, 1978: 127-39).

${ }^{4}$ A primary budget surplus is achieved when total government revenues exceed total expenditures before debt service.

${ }^{5}$ Euro Summit Statement, SN 4070/15, Brussels 12/07/2015.

${ }^{6}$ 'Comprador' refers to capital that is rooted and operates in a national setting, as a bub for external capital.

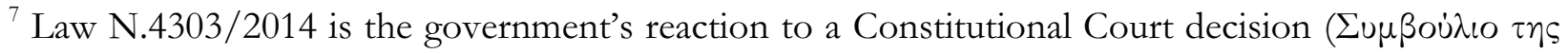

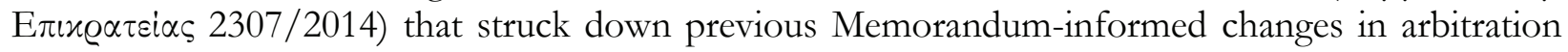
as unconstitutional (Amargiotakis, 2015: 12-13; Deakin and Kouliadaki, 2013: 181; Voskertsian and Kornelakis, 2011: 13-16).

${ }^{8}$ Certainly, enhanced profitability can be a factor of 'competitiveness', helping attract investment and so on. Yet, while 'competitiveness' refers to the national/regional economy and therefore appeals to the 'common good'; it is in fact nothing but a class strategy that benefits capital. Especially in the Greek case - which is seeing competitiveness through suppression of labour and social costs, not through rise of productivity, new technologies, R\&D and so on - the 'common good' of competitiveness is not only pro-capital but also decisively anti-labour.

${ }^{9}$ On exceptional states see Poulantzas (1974).

${ }^{10}$ The fact that state structures are not neutral has been described as 'strategic selectivity'. This refers to 'the ways in which the state considered as a social ensemble has a specific, differential impact on the ability of various political forces to pursue particular interests and strategies in specific spatio- 
temporal contexts through their access to and/or control over given state capacities' (Jessop, 2002: 40).

${ }^{11}$ None of this is new. European monetary integration, which began in earnest in 1979 with the European Monetary System of fixed but adjustable exchange rates, was always skewed in favour of an economic model based on liberal economic and social policies and price stability. Introduction of the common currency further deepened these features by making the ECB fully independent and committed to the goal of price stability rather than macroeconomic goals.

12 A full examination of the EU power bloc is outside the scope of this paper, but see Van Apeldoorn (2013) for a recent analysis, including the conflict of interests for European capitalists for whom austerity is a profitability-boosting reduction of wage costs, but also a revenue-endangering reduction of aggregate demand.

\section{REFERENCES}

Amargiotakis, M. (2015) Changes in Labour Issues from 2010 Onwards. Available online at http://www.ergasiaka-gr.net/2015/01/Oles-oi-allages-sta-ergatika-apo-to-2010-mexrisimera.html\#.VV0d2PIVhBd; accessed: 20 May 2015. (In Greek).

Armingean, K. and Baccaro, L. (2012) Political Economy of the Sovereign Debt Crisis: The Limits of Internal Devaluation. Industrial Law Journal, 41(3): 254-75.

Boukalas, C. (2014) Homeland Security, Its Law and its State. Abington: Routledge.

Buckel, S. (2011) The Juridical Condensation of Relations of Forces: Nicos Poulantzas and Law. In Reading Poulantzas, edited by Alexander Gallas, Lars Bretthauer, John Kannankulam and Ingo Stutzle. Pontypool: Merlin.

Chrissogonos, C. (2013) The Circumvention of the Constitution in the Era of the Memoranda. Athens: Livanis. (In Greek).

Daouli, J.J., Demoussis, M., Giannakopoulos, N. and Laliotis, I. (2013) The Impact of the 2011 Collective Bargaining Reform on Wage Adjustments in Greece. Draft Paper, University of Patras.

Deakin, S. and Koukiadaki, A. (2013) The Sovereign Debt Crisis and the Evolution of Labour Law in Europe. In Resocialising Europe in a Time of Crisis, edited by N. Countouris and M. Freedland. Cambridge: CUP.

Demirović, A. (2011) Rule of the People? Democracy and the Capitalist State in the Work of Nicos Poulantzas. In Reading Poulantzas, edited by Alexander Gallas, Lars Bretthauer, John Kannankulam and Ingo Stutzle. Pontypool: Merlin.

Efsyn (2015) Pre-memorandum Moves. Efsyn, 30 June 2015. [In Greek].

Etievant, G. (2015) Soyons prêts à sortir de l'euro. Available online at http://guillaumeetievant.com/ 2015/07/24/soyons-prets-a-sortir-de-leuro/;_accessed 14 August 2015.

European Commission (2010a) The Economic Adjustment Programme for Greece - First Review. Occasional Papers 68. Brussels: Directorate General for Economic and Financial Affairs.

European Commission (2010b) The Economic Adjustment Programme for Greece - Second Review. Occasional Papers 72. Brussels: Directorate General for Economic and Financial Affairs.

Global Labour Journal, 2015, 6(3), Page 402 
European Commission (2015) Annual Macro-economic Database. Available online at http://ec.europa.eu/economy_finance/db_indicators/ameco/index_en.htm; accessed April 2015.

Evans-Pritchard, A. (2015) Europe is Blowing Itself Apart over Greece. The Telegraph, 7 July 2015.

Financial Times (2015) Schäuble Outlines Plan to Limit European Commission Powers, 30 July 2015.

Greek Government (2011a) Ministerial Order No.1.5131/OIK.3949: Promotion of employment through public benefit programmes for the year 2014-2015. Paper of the Government of the Greek Republic (ФEK), Issue 3172. 26 November. (In Greek).

Greek Government (2011b) Ministerial Order No.1.5188/OIK.3.968: Unitary system of administration, evaluation and control of professional training actions .... Paper of the Government of the Greek Republic (ФEK), Issue 915. 20 May. (In Greek).

Greek Government (2014a) Ministerial Order No.4.31879/OIK.3.1604: Creation of employment positions at local level through public benefit programmes. Paper of the Government of the Greek Republic (ФEK), Issue 613.15 April. (In Greek).

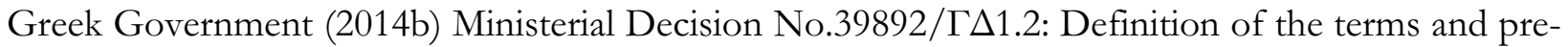
requisites for the implementation of pilot programme Minimum Guaranteed Income. Paper of the Government of the Greek Republic (ФEK), Issue 3018. 7 November. (In Greek).

GSEE (2015) Press Release, Athens, 1 July 2015. Available online at http://www.gsee.gr/deltiotipou-sinedriasi-olomelias-diikisis-gsee-3/; accessed 23 July 2015.

Hellenic Statistical Authority (2015) Labour Force Survey 1st Quarter 2015. Available online at www.statistics.gr/portal/page/portal/ESYE/BUCKET/A0101/PressReleases/A0101_SJO01_ DT_QQ_01_2015_01_F_EN.pdf; accessed 8 August 2015.

Holezas, J. (2014) Actions to Counter Unemployment. Greek Economy: Monthly Bulletin on Economic Developments, 1, January. (in Greek)

Holman, O. (2004) Asymmetrical Regulation and Multidimensional Governance in the European Union. Review of International Political Economy, 11(4): 714-35.

Jessop, B. (1982) The Capitalist State. Oxford: Blackwell.

Jessop, B. (2002) The Future of the Capitalist State. Cambridge: Polity.

Jones, O. (2015) The Left must put Britain's EU Withdrawal on the Agenda. The Guardian.com, 14 July 2015. Available online at http://www.theguardian.com/commentisfree/2015/jul/14/leftreject-eu-greece-eurosceptic.

Kentra Epaggelmatikis Katartisis (KEK) (2015) Voucher Programme. Available online at http://www.voucherkek.gr/voucher.html; accessed 6 May 2015.

Lapavitsas, C. (2013) Profiting Without Producing: How Finance Exploits Us All. London/New York: Verso.

Mackintosh, J. (2015) Deutsche Bank on Greece Deal. Twitter, 13 July 2015. Available online at https://twitter.com/jmackin2/status/620544942641786880; access 7 August 2015.

Oberndorfer, L. (2014) A New Economic Governance through Secondary Legislation? Analysis and Constitutional Assessment: From New Constitutionalism, via Authoritarian Constitutionalism 
to Progressive Constitutionalism. In The Economic and Financial Crisis and Collective Labour Law in Europe, edited by N. Bruun, K. Lörcher and I. Schömann. Oxford: Hart.

Poulantzas, N. (1974) Fascism and Dictatorship. London: NLB.

Poulantzas, N (1978) State, Power, Socialism. London: NLB.

Sablowski, T. (2015) Die Etappenschlappe. Junge Welt, 18 July 2015. Available online at http://www. jungewelt.de/2015/07-18/014.php.

Skya (2015) Workfare Reloaded: Struggles Against the Imposition of Work as Benefit'. Assembly for the Circulation of Struggles. Athens, January. (In Greek).

Syriza (2014) Governmental Programme for Labour Relations. Athens, 4 September. (In Greek).

The Guardian (2015) How Athens Voted, 9 July 2015. Available online at http://www.theguardian.com/news/datablog/ng-interactive/2015/jul/09/greek-referendumhow-athens-voted-interactive-map; accessed 20 July 2015.

The Press Project (2015) They Want Wages at 300 Euros. 28 May 2015. Available online at http://www.thepressproject.gr/article/77572/Sta-300-euro-theloun-tous-misthous. accessed 4 June 2015.

TVXS (2015) Public Prosecutor Investigates the Coverage of the Referendum by TV Channels (in Greek). Available online at http://tvxs.gr/news/internet-mme/eisaggeliki-ereyna-gia-tinkalypsi-toy-dimopsifismatos-apo-ta-kanalia; accessed 20 July 2015.

Van Apeldoorn, B. (2002) Transnational Capitalism and the Struggle over European Integration. Abington: Routledge.

Van Apeldoorn, B. (2013) The European Capitalist Class and the Crisis of its Hegemonic Project. Socialist Register, 50: 189-206.

Varoufakis, Y. (2015) I Will Not Vote for the Eurotop Proposal. Yanis Varoufakis's interview to The Press Project, 14 July 2015. Available online at http://www.thepressproject.gr/article/79198/GBaroufakis-sto-TRR-Den-tha-psifiso-tin-protasi-tis-Sunodou-Korufis; accessed: 20 July 2015. (In Greek).

Villers, C. (2014) Post-crisis Corporate Governance and Labour Relations in the EU (and Beyond). Journal of Law and Society, 41(1): 73-94.

Voskertsian, H. (2015) Why Bargain Collectively? Bristol: Centre for Employment Studies Research.

Voskertsian, H. and Kornelakis, A. (2011) Institutional Change in Greek Industrial Relations in an Era of Fiscal Crisis. GreeSE Paper no.52. London: Hellenic Observatory on Greece and Southeast Europe.

Voucherades (2015) Voucherades Blog. Available online at http://vforvoucherades.blogspot. co.uk/p/blog-page_2.html; accessed 6 May 2015.

Ziltener, P. (1999) Strukturwandel der europäischen Integration: Die Europäische Union und die Veränderung von Staatlichkeit. Münster: Westfälisches Dampfboot. 


\section{BIOGRAPHICAL NOTES}

CHRISTOS BOUKALAS is a Law and Society research fellow in Cardiff Law School, and author of Homeland Security, its Law and its State - A Design of Power for the 21st Century (Routledge, 2014). His current research project on the Pre-emptive Turn in UK Criminal Law and Policy is sponsored by the Journal of Law and Society. He has a PhD in state theory from Lancaster University (Department of Sociology) and expertise in contemporary American counterterrorism policy. He has accomplished an ESRC-sponsored research project on Counterterrorism Policy: Law, the State and Implications for the Polity (Centre for Law and Society, Lancaster University). His research interests include political and state theory, counterterrorism, theory of law, criminal law and theory of democracy. He has published several articles and book chapters in these areas. [Email: boukalasC@cardiff.ac.uk]

JULIAN MÜLLER is a sociologist by training. He specialises in critical political economy, especially the political economy of finance and accounting on which he did a PhD at Lancaster University. After a stint as a super-precarious freelance translator he now works for the Dutch NGO SOMO, especially on issues of financial sector regulation. [Email: julianporto@gmx.de] 